\title{
The Board President's Role in Controlling the Decision-making Process in Voluntary Sports Organizations
}

\author{
Jorge Alexandre Pereira Soares ${ }^{\dagger}$ \\ University of Madeira
}

\begin{abstract}
The goal of the study is to understand the president's influence and his skills in the strategic decisionmaking process. The qualitative nature of the study implied a participant's observation during board meetings (with a total of 35 sports directors -3 professionals and 32 volunteers), as well as interviewing the six board presidents of the sports associations that are part of the study. The main results revealed a poorly structured decision-making process, but with a determinant role of the board president in the conduction and manipulation of the said process. This was especially evident with the professional sports directors who showed higher knowledge and better preparation of the subjects. Likewise, both of the associations headed by full-time professional sports directors, along with an association led by a volunteer sports director (though strongly backed by the technical director of sport or sports manager during the meetings and decision-making), revealed greater strategic management and better organizational results. The main power sources of the board president, and the skills he uses in order to mark the decision's direction are internal alliances with the closest sports director (volunteer and professional), anticipation through a previous expressed opinion, the use of information, sports expertise, and also the knowledge regarding the existent problems among the clubs and the affiliated coaches. The results found bad governance which shows confusing and poorly structured management practices. This study intents to contribute for the change of the relationship between the role of the board and the technical director of sport or sport manager (specially for the relevance of the last), in order to improve better strategic decision-making in the non-profit sport organizations.
\end{abstract}

Keywords: Strategic Decision-Making; Governance; Voluntary Sports Organizations; President; Board.

*Author for correspondence:

$\uparrow$ Professor Auxiliar Institution: Universidade da Madeira Address: Campus da Penteada, $n^{\circ} 9000$ Funchal, Portugal E-mail: jorges@staff.uma.pt 


\section{INTRODUCTION}

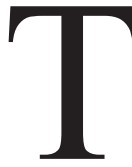

he positions and functions that voluntary directors and sports managers hold and carry out within sports organizations may be analyzed in the light of how the personal interests and sources of powers of these actors influence decision-making. In accordance with the political model and governance in sports organizations, interests and internal alliances may constitute veritable sources of power within the boards and management of sports organizations (HEALEY, 2012; HOYE; CUSKELLY, 2003; HOYE; CUSKELLY; 2007; MINTZBERG, $1989 ; 1995)$. It is possible to analyze these alliances not only in the light of power games, but also taking into account the existent groups of interests, be internal or external, within the sports system, which is open and dynamic. Indeed, there are evident partnerships, contracts, agreements, groups of pressure, favors, etc. This often leads to misunderstanding concerning the role of each actor. Thus, the promiscuity of the duties and positions within the structure and strategic management are common in bad governance (HOYE, 2007; INGLIS, 1997; ROBINSON; PALMER, 2011).

Governance practices are based on codes, which are a set of norms governing the role and composition of the board of sports associations and clubs, relationships within it, auditing and information disclosure, and the recruitment and dismissal of directors and senior managers (AGUILERA; CUERVO CAZURRA, 2004; HOYE; CUSKELLY; 2007; SCHULZ; AULD, 2006; SOARES, 2013). In a governance system, the board is a critical mechanism. Indeed, its main responsibility is to ensure that the activities of the organization are carried out in the best interests of the organization, its members and society (YEH; TAYLOR, 2008). In a nonprofit organization the board has not the goal of making profits, and when that happens, those profits should be delivered to its members or the individuals that the organization serves (HOYE; CUSKELLY, 2007). In the volunteer sport organizations, the most common governance structure is a volunteer board at the hierarchy of authority (KIKULIS, 2000). In a good governance evaluation it is very important to make clear what the role of the board is. It is also important to have a clear definition of the professional sports manager's role, in order to get the best results for the organization. The relationship between the board and the sports manager must be characterized by mutual trust these two organizational actors, and by a reciprocal commitment to achieve common and strategical objectives (PALMER, 2011).

In the absence of good practices of governance regarding integrity, neutrality and transparency in the management of voluntary sports organizations, these ought to be regulated by independent institutions. When there are visible interference and conflicts of interests from the authorities, as well as from the national and international federal structures that coordinate and integrate the local associations and sport clubs (SOARES; CORREIA; ROSADO, 2010), it is mandatory to regulate the roles of the actors and voluntary organizations. This ensures the principles underlying good 
governance and the proper use of the public resources provided (HUMS; MACLEAN, 2013). As a matter of fact, recent investigations demonstrate a positive relationship between organizational performance and professionalization in human resources (MADELLA; BAYLE; TOME, 2005; NAGEL et al.;2015), and better corporate governance had a positive effect on the firms' market value (BLACK; JANG; KIM; 2006; CAIXE; KRAUTER; 2014). Sports organizations headed by volunteers sports directors, but using more rational and structured practices in their management, are committed with better strategic results (BROWN, 2005; FERKINS; 2010; FERKINS; SHILBURY, 2012; FERKINS; SHILBURY; MCDONALD, 2005). A sport marketing thinking and strategy is also necessary to achieve a sustainable programs and a competitive advantage. Many organizations, including sports associations, use sports marketing as a way to position themselves for competitive advantage, as well as to give sports a business orientation (RATTEN, 2016).

\section{Theorical Framework}

In the process of decision-making, the chairman's leadership role in organization's board is crucial (FERKINS; 2009; MINTZBERG; QUINN; GHOSHAL, 1995). Nevertheless, the dynamic of the group is also of great importance for the organizational performance's improvement (BROWN, 2005).

This process may assume features that reflect the leadership style adopted by the board president according to the decision model (VROOM; JAGO, 1988). The normative decision model is a decision-making tree that enables a leader to examine a situation and determine which style or level of involvement to engage. This model identifies three styles along a continuum, ranging from autocratic, to consultative and group-based: autocratic, in which the decision is solely the responsibility of the president; consultative in which the president merely takes into consideration the contribution of other members before making a decision; and lastly, the participation group or team decision, when the decision is made together with the participation of the board members and can be accomplished by vote or consensus. This model is appropriate to understand the relationship between the board president, the board members and the sports manager or technical director of sport in non-profitable sportive organizations managed by volunteers. By asking oneself a series of questions about the nature of the problem, decision, and consequences, the leader can decide just how much involvement others should have in the decision. The analysis of the role that the president plays in the control of the decision process is crucial in order to understand with whom the actors are engaged and committed in the strategic management.

The option for the continuum model of leadership (VROOM; JAGO, 1988) was mainly due to the fact that the board presidents are the key actors in conducting and orientating the tasks of the voluntary sports organizations. These organizations are remarkably featured by non-structured and inefficient on the strategic point of view. Moreover, leaders use certain skills and play with power 
sources, be them internal or external, to make a strong influence within the process of decisionmaking (SOARES; CORREIA; ROSADO, 2010).

According to the stakeholder theory for non-profit sport organizations there are many stakeholders, and most of them have different interests to defend and preserve. In this context, sport associations have to balance the interests of the various stakeholders, and thus the primary board's role is to identify, understand and satisfy the demands of each stakeholders (CARVER, 1997; CLARKE, 2004; YEH; TAYLOR, 2008). However, as sports associations develop their own financial independence and are able to create and implement sport achive strategic objectives, they become more capable to negotiate and to promote specific activities. For instance, a regional sport competition or a national sport event to satisfy demands of sport athletes and sport clubs. To be efficient, the board has to develop a good relationsship with the managers and sport directors of stakeholders. This relationship should be dynamic. Moreover, some alliances and agreements are very useful for the effectiveness of the organization. For example, in voluntary sport associations the influence and the power of the president of the board increases has he or she can a develop a strategic management in an open and profitable relationship with external organizations. In order to understand the specific external environmental and different stakeholders connected with the sport associations we decided to present a contextual setting.

\section{Contextual Settings}

Sports associations are private but nonprofit sport organizations. The mission of the sport associations is to promote and coordinate the practice of a specific sport activity, including the sport competition for sport clubs and teams that are affiliated in the federated sport. In general, they perform a service in the public interest which is acknowledged by the public administration or the State. As such, the associations benefit from financial support which is made available by the local and regional public administration. Macro-analysis reveals that sport associations form a component of sports infrastructure. For instances, Madeira Autonomous Region establishes close links and dependencies with the region's Sports Institute (regional public administration for sport). In spite of the fact that the associations are legally independent, they depend on ordinary subsidies (monthly financial support that underpins the structure and running of the organizations' activities) and extraordinary subsidies (financial support that permits the implementation of projects such as participation in high-level sports events). In the context of sport Madeira development, it is evident that the public funds constitute an indispensable element in the functioning of sport association, particularly when the latter does not has its own sufficient resources to conduct its activities (FERNANDES; LUCAS, 2003). This explains how organized sporting activities have developed in Madeira (within the framework of the region's political and administrative competences), by 
means of a policy that has established a range of financial partnerships based on programmecontracts, of which the associations and/or clubs are signatories.

At the national level, the sports associations are generally affiliated with their sport federation, participating in the main issues arising from the development rules, plans, sport competition frameworks and regulations governing national competitions. At the local and regional level, the sport associations represent one of the major intermediaries in the promotion of the sport association movement, playing a vital role in the growth and development of sport clubs and in the training and guidance of athletes who demonstrate outstanding talent or potential. For example, they define the rules to decide which athletes should be attended in special training sessions for best athletes, in order to prepare them for top-level competition.

In the sport associations, there are two levels of sport management (Figure 1). At the top of the board, we identify volunteer sport directors that have the responsibility of making a strategic decision. In the board we also can identify sport managers (professional) that help the board to make better and rational decision (SOARES; CORREIA; ROSADO, 2010).

In the intermediate management - technical department -, one can finds port directors or sport coordinators and sport managers. Those who have the responsibility to manage the professional members of the department, for example, the sport coaches. At this level we are able to identify tactical decisions and humans resources management of operational and intermediate level. As this associations are sport organizations they deal with sport issues connected with rules of competition; criteria to organize the schedule of regional sport competition; sport coach meetings to organize the

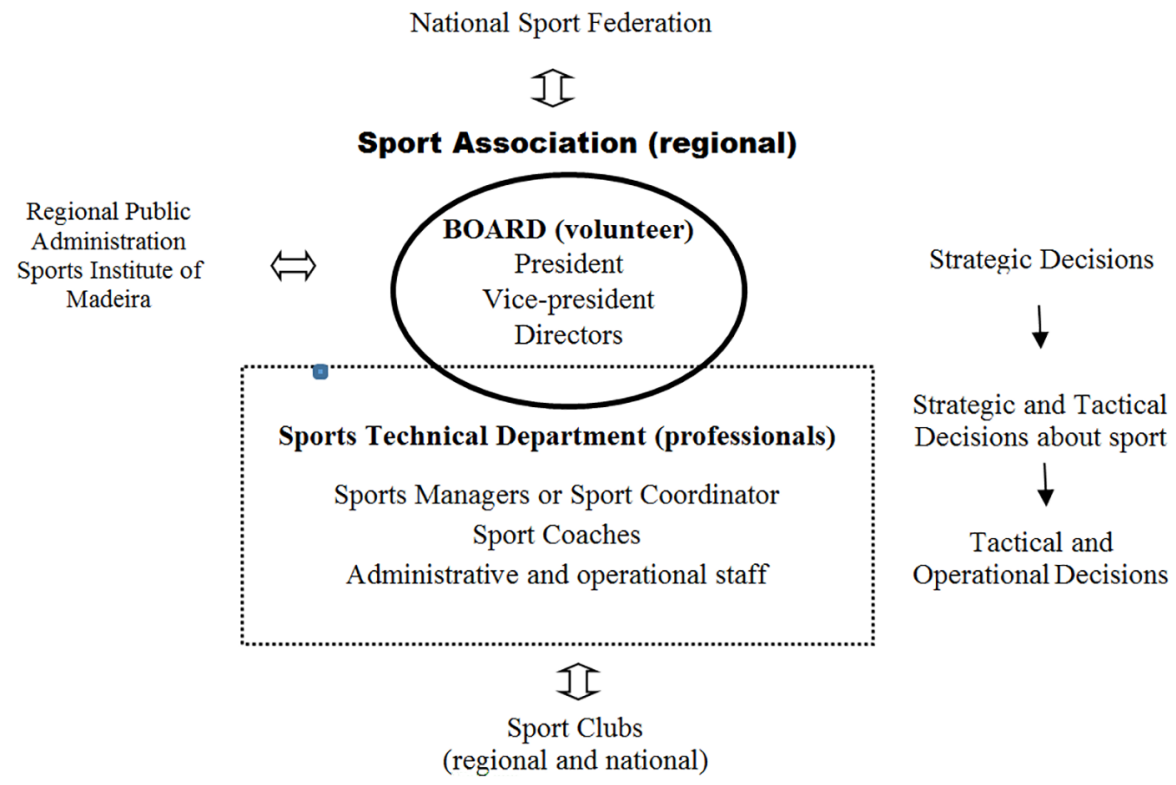

Figure 1. The organizational structure of sport association in relationship with thestakeholders and the levels of the decisions. 
special training for best athletes (sport talents); ethic codes and best practice to promote a positive and respectable atmosphere between sport clubs actors.

To understand the role of the sport director (volunteer and professional) in the board, we should emphasize that this sport directors are elected from the sport clubs affiliated. This means that these organizations are based in stakeholder theory as they are depending on decisions that are made in the general assembly and informal decisions between the sport organizations which have the power and interests to defend (CLARKE, 2004; YEH; TAYLOR, 2008).

To identify a descriptive characterization of the dimension of sport associations Table 1 presents a quantitative indicators of the national and international athletes, the sport clubs affiliated and the volunteer and professional sport directors in the board of these organizations.

Table 1. Characterization of the Sport Association according to the sport clubs affiliated, national and international athletes (source: Regional Department for Sports, Federated Sports, 2014)

\begin{tabular}{|c|c|c|c|c|c|c|c|c|}
\hline \multirow{2}{*}{$\begin{array}{l}\text { Sports } \\
\text { Associations }\end{array}$} & \multirow{2}{*}{$\begin{array}{l}\text { Sport clubs } \\
\text { affiliated } \\
\text { (N) }\end{array}$} & \multicolumn{3}{|c|}{$\begin{array}{l}\text { Athletes in Madeira and } \\
\text { Portugal }\end{array}$} & \multicolumn{2}{|c|}{$\begin{array}{l}\text { International } \\
\text { Athletes }\end{array}$} & \multicolumn{2}{|c|}{ Board members } \\
\hline & & $\mathrm{N}$ & Madeira & Portugal & $\mathrm{N}$ & $\%$ & $\begin{array}{l}\text { Volunteers } \\
\text { (N) }\end{array}$ & Professionals $(\mathrm{N})$ \\
\hline Basketball & 10 & 956 & $6.50 \%$ & $7.93 \%$ & 11 & - & 5 & 1 \\
\hline Gymnastics & 7 & 829 & $5.64 \%$ & $4.28 \%$ & 2 & - & 4 & - \\
\hline Athletics & 17 & 148 & $1.00 \%$ & $9.18 \%$ & 2 & 5.41 & 5 & - \\
\hline Canoeing & 5 & 249 & $1.69 \%$ & $3.89 \%$ & 3 & 10.34 & 6 & - \\
\hline Table Tennis & 27 & 1,306 & $8.88 \%$ & $29.20 \%$ & 24 & 61.53 & 5 & 2 \\
\hline Volleyball & 13 & 663 & $4.51 \%$ & $4.05 \%$ & 2 & 2.89 & 7 & - \\
\hline
\end{tabular}

In this context, the goal of this study is to analyze the president's role within the voluntary sports associations' board, in order to understand his or her influence, as well as the power sources that he or she uses in the decision-making within these organizations. For better understand the structure and the process of decision-making within the board of sports associations, a qualitative study was applied.

\section{METHOD}

To better comprehend the process of decision-making and the actors' game influences, it was fundamental to use data collection techniques that require an active and close involvement with the key members and sports directors. Indeed, every social phenomenon is better understood when observing the actions and decisions developed in their natural context (MAXWELL, 2013; SHILBURY; FERKINS; SMYTHE, 2013). In this way, the awareness and comprehension of the observed phenomenon, usually requires systematic and appropriate follow-up meetings. It also might require an active participation in the subjects of the studied board associations. Moreover, in a longitudinal study, it is possible to use and to develop a triangulation of different kind of data 
(e.g., participant observation and directive interview) in order to interconnect, clarify, confirm and to deepen the produced knowledge.

Two techniques were used for data collection in this study: participant's observation of board meetings (a passive observation that sometimes was interrupted; whenever the researcher had doubts he asked for clarifications) and directive interviews applied to the presidents of the associations' boards of six sports associations of a total of twenty (30\%). The interview-guide was raised by the observation data; its goal was to better understand and interpret the data gathered from the observation. Firstly, during board meeting observations, the participants' role and their influence was identified in the decision-making process, including the sports manager or the technical director of sport. Then, through observation, it was possible to analyze the data, to reduce and select data and construct a category system (participants and power source), and consequently, understand the nature of the decision-making process and the influence of the members with responsibilities in the board.

The study involved the following sports activity associations: Athletics, Basketball, Gymnastics, Canoeing, Table Tennis and Volleyball, and a total of 35 sports directors of board associations (all participants were men except on). Six presidents of the board associations were included in the interview process. These associations are private and autonomous organizations, but they do not seek to make profit from their activities. Overall, they perform a service in the public interest, which is acknowledged by the public administration, so they benefit from financial support, which is made available by the regional and local administration. These associations are also relevant when it comes to defend the interests of their sports clubs affiliated in the national sports federation's assemblies.

The organizations were randomly selected by invitation. Afterwards, an agreement was assigned and the actor's anonymity was guaranteed, along with the confidentiality of the data for scientific use. In this study, there was no conflict of interests between the researcher and the studied organizations.

All of the six abovementioned associations' presidents of the board and 29 board members (vice-presidents and sports directors, who, with the exception of three, were all amateurs) took part in the observation stage. In several phases of the study, it was also necessary to consult specific documents related with the organizational structure (Statute and Rules of Procedures), and related with the federated demography in what concerns the strategic results of the organizations in the study, namely: number of athletes and affiliated clubs in the association, as well as the sports results and rankings at the national and international levels.

Descriptive analyses of the decision-making process were developed in accordance with the continuum model of leadership (VROOM; JAGO, 1988), along with the factors that might 
influence the decision-making of the board. This model is appropriate to understand the relationship between the board president, the board members and the sports manager or technical director of sport in non-profitable sportive organizations managed by volunteers. By asking oneself a series of questions about the nature of the problem, decision, and consequences, the leader can decide just how much involvement others should have in the decision. The analysis of the role that the president plays in the control of the decision process is crucial, so we can understand with whom the actors are engaged and committed in the strategic management. Through the content analyses of the observation memos of the board meetings and the interviews, it was possible to detect several categories, which were crucial in the process of decision-making.

\section{RESULTS AND DISCUSSION}

\section{Actors and the nature of their participation on the board}

The observation of the board meetings allowed identifying and confirming the data related to actors' identification and their role within the organizational structure, particularly in the decision-making process. Table 2 identifies the set of actors who integrate the organizational structure, namely in the following unites: direction (board), technical department administrative and operational. Only two associations were led by professional sports directors, though both of them were on a seconded situation (a year of mobility that a Physical Education professional took from public administration to work, in this case, in the sports association). Moreover, one of the two associations also had another director on a seconded situation (the board vice-president). The remaining four associations were headed by volunteer directors. According to the gathered data through the interviews, these volunteer directors did not receive any kind of financial compensation for their position as sports directors.

It has been found that all the associations hire people under the figure of 'seconded' at the technical background level. The presence and the participation of technical director of sport in the board meetings only happen in the Basketball Association. In this organization, the technical director of sport and his colleague (member of sport department) have actively participated in the board meetings since the moment they entered in the association, as if they were another elected sports directors. In other associations, we are able to observe specific features of the structure and the role of sport directors that demonstrate an accumulation of positions and group interests. In the Gymnastic Association, the volunteer sports director (responsible for the sports activity) took on the liaison with all the professional technical elements. Even though he was not seconded, as other technical directors, he maintained that connection regardless the field or the sports discipline. The specific position of sports manager (as a formal position) was not found in any of the studied 
Table 2. Board organizational structure of the sports associations and services under their responsibility

\begin{tabular}{|c|c|c|c|}
\hline Sport Association & $\begin{array}{l}\text { Board Directors (all } \\
\text { volunteers, except three that } \\
\text { were professionals seconded } \\
\text { position) }\end{array}$ & $\begin{array}{l}\text { Technical Sports Department } \\
\text { (Professionals) }\end{array}$ & $\begin{array}{l}\text { Administrative and } \\
\text { operational staff }\end{array}$ \\
\hline Basketball & $\begin{array}{c}\text { President } \\
\text { Vice-president } \\
\text { Treasurer } \\
\text { Voting member }\end{array}$ & $\begin{array}{c}\text { Sports Coordinator } \\
\text { (professional seconded) } \\
\text { Assistant Team Coach } \\
\text { Team Coach }\end{array}$ & $\begin{array}{c}\text { Employees }(\mathrm{N}=3) \text { One } \\
\text { multipurpose collaborator to } \\
\text { support the national teams' } \\
\text { activities }\end{array}$ \\
\hline Gymnastics & $\begin{array}{c}\text { President } \\
\text { Vice-president } \\
\text { Administrative Director } \\
\text { Director of Finance } \\
\text { Directors }(\mathrm{N}=2) \\
\text { Director of Sport }\end{array}$ & $\begin{array}{l}\text { Coach for Category B Coach } \\
\text { for Category C (professional } \\
\text { seconded) }\end{array}$ & Employees $(\mathrm{N}=2)$ \\
\hline Athletics & $\begin{array}{l}\text { President (professional } \\
\quad \text { seconded) } \\
\text { Vice-presidents }(\mathrm{N}=5)\end{array}$ & $\begin{array}{l}\text { Sports Coordinator } \\
\text { (seconded) } \\
\text { Coach (professional } \\
\text { seconded) } \\
\text { Coach } \\
\end{array}$ & Employees $(\mathrm{N}=2)$ \\
\hline Canoeing & $\begin{array}{c}\text { President } \\
\text { Vice-president } \\
\text { Treasurer } \\
\text { Voting members }(\mathrm{N}=2)\end{array}$ & $\begin{array}{c}\text { Sports Coordinator } \\
\text { (professional seconded) }\end{array}$ & One employee \\
\hline Table Tennis & $\begin{array}{c}\text { President (professional } \\
\text { seconded) } \\
\text { Vice-president (professional } \\
\text { seconded) } \\
\text { Voting members }(\mathrm{N}=5)\end{array}$ & $\begin{array}{l}\text { Board (professional seconded) } \\
\text { Vice-president (professional } \\
\text { seconded) } \\
\text { Coaches }(\mathrm{N}=2 \text { ) } \\
\text { Invited Club Coaches (up to 13) }\end{array}$ & $\begin{array}{c}\text { Employees }(\mathrm{N}=4) \\
\text { A driver } \\
\text { A bellboy } \\
\text { A cleaning lady }\end{array}$ \\
\hline Volleyball & $\begin{array}{c}\text { President } \\
\text { Vice-president } \\
\text { Director of Finance } \\
\text { Secretary-General } \\
\text { Director of Human \& } \\
\text { Material Resources } \\
\text { Director of Activities } \\
\text { Director of Marketing \& } \\
\text { Publicity }\end{array}$ & $\begin{array}{c}\text { Sports Coordinator } \\
\text { (professional seconded) } \\
\text { Coach (professional } \\
\text { seconded) } \\
\text { Training Centre Coach } \\
\text { (part-time) }\end{array}$ & An administrative assistant \\
\hline
\end{tabular}

organizations. Nevertheless, the functions of the professional and volunteer sports directors, as well as the technical director of sport, were easily linked to the tactical and strategic management's role, that is, linked to the role of a sports manager in a sports organization.

In what regards the technical director's sports role, it was found that Athletics Association did not integrate anyone for that position, as the president explained it. It was this leader who took most of the tasks related to technical coordination, although he had the support of two other sports technicians. The technical director of sport of Canoeing Association, who was recruited several 
weeks before the observations has ended, did not participate in the board meetings - though he was seconded. Only after the process of analysis and interpretation of the memo's observations, regarding the actor's role in the decision-making process, it was possible to perceive that the board vice-president, along with a club's coach, was the key element to connect the board decisions with the technical elements of the remaining clubs. This vice-president assumed several technical functions. According to the president's explanation, the intervention of the new technical director was limited to:

"Boosting projects related to the sports discipline's promotion at schools and at the level of tourist industry activities" (Observation and interview).

In the Table Tennis Association, it was found that the president was the element that ran the technical department - an advisory body - constituted by 13 coaches, invited by the board. That might be the reason why we did not find any element with specific functions for the sportive technical area. Finally, in Volleyball Association, taking into account the present members, any direct or systematic intervention from the technical director of sport was not found during the board meetings.

After a global analysis of the organizational structure of the board, it was possible to notice a certain promiscuity of positions and roles. This fact clearly indicates a lack of formalization and specialization of the positions and functions, including positions with a professional nature, namely technical direction or sports management.

The administrative employees were part of the structure in all sports associations. Only one of the associations was limited to a single administrative. It was also observed that the ratio of the administrative staff number it is not proportional to the registered athletes or the association magnitude (number of affiliated clubs). However, the largest association (Table Tennis) incorporates four administrative employees and three operational staff in full-time basis. See Table 1 and Table 2 to understand the size and dimension of the sport associations and the role of the professional and the volunteer sport director.

The Basketball Association was the only one in which we observed the administrative employee's participation in the direction's work. This employee was mainly working with

administrative issues such as information related with registrations, invoice operations and payments, and process of drawing up releases. The role of this employee could be confirmed by the 24 interventions held during five board meetings.

\section{The president's role in the management of the decision-making process}

The results show that the process of decision-making, when it comes to groups or teams, can take three kinds of categories: C1) when the decision is made and shared through the agreement 
between two or more persons (as an alliance, for instance) with decision power; generally with the participation and connivance of the president, while the remaining elements usually maintain themselves in silence (which might mean their indifference or agreement); C2) when the decision is cleared by a voting process, or simply by the majority's expression, in conformity with the statutory procedures; C3) lastly, when the decision-making process arises from a fruitful, and open discussion; and thus, gathering the contribution or agreement of all the elements, either explicitly or implicitly, or at least tendentiously consensual.

The first subcategory emerged throughout the analysis and codification of the text units, which resulted from the observation. In this way, even though there exists a team's decision-making, this could happen through an agreement or alliance between two or three elements (usually the president and the vice-president), while the other elements remained in silent or indifferent. Most of the time, this fact was interpreted as an accordance, or as the saying goes: 'silence means assent'.

As an alternative to team decision-making model, one can find the model centralized in the president (autocratic). In this model, the president gathers all the information he or she needs from his or her board colleagues, or other sources, and then makes his or her decision. In this situation, the president does not need to clarify or even explain the problem; and the colleagues do not have any direct influence in the decision.

In an intermediate level of influence one can find the model of query. In this model, the president shares the problem with all members, takes into account the different points of view, as well as each contribution, and only then the president decides. Nevertheless, this decision it may or may not reflect the group's opinion.

The most relevant result points to the fact that $63.66 \%$ of the decisions are an outcome of the board meetings. The decisions either strategic or tactic belong to the category 'consensual' or 'primarily consensual'. Although distant from the consensual model, the decision-making process that is a consequence of an agreement between two or more elements (especially the president and vice-president) appears as the second major result (13.45\%). The alliance between the two directors, when associated to control of the information flow, might represent two sources of power for the decision-making process (this explanation will be developed afterwards).

The third result that deserves especial attention is the fact that the decision-making by query $(12.18 \%)$ is higher than the others styles of decision-making: autocratic (7.35\%) and voting process $(3.36 \%)$.

\section{Power sources that influence the decision-making}

By an inductive process we have identified specific categories that explain the role of the president in the managing the decision making process. These categories presented in Table 3 were 
found in the observation meetings of the board during seven months and confirmed by the interviews that were made.

\section{Information control in the sports discipline's context}

The results show the importance of information control regarding the decision-making process by the president, who had the responsibility to prepare and head the board meetings. In this context, the knowledge about all issues and files, particularly by the president and the technical director of sport, was of great influence in the decision-making process.

In fact, this finding was determinant in the two associations headed by professional presidents. It is likely that being well aware of the information, as well as the higher level of preparation have had great influence for the decision-making. Instead, in the associations less prepared and with a president less available, the problem was rectified with the support and the information provided by the technical director or the vice-president. The following memo illustrates the above mentioned observation:

Table 3. Categories that explain the role of the President of the board in influencing the decision-making process in sport associations

\begin{tabular}{ll}
\hline Category & \multicolumn{1}{c}{ Definition and features } \\
\hline & $\begin{array}{l}\text { The use of information as a source of power by the president of the board. As the } \\
\text { president has more knowledge of the issues, the influence in the decision-making } \\
\text { process increases. For example, the mastering information related to competition, } \\
\text { arbitration and sports ranking of the sports association, are very important to influence } \\
\text { the colleagues in the decision-making process. }\end{array}$ \\
\hline Alliance between two or more & $\begin{array}{l}\text { The establishment of alliances or agreements between two leaders, in general between } \\
\text { the president and the vice-president to propose a solution, represents a source of } \\
\text { Actors }\end{array}$ \\
& influence in the decision-making process. \\
& When this alliance is presented before the discussion phase, could influence the others \\
& sport directors (volunteers) to follow the solution proposed.
\end{tabular}

Knowledge, experience and skills in the sport field are very important to influence

Director's experience and involvement in the sports discipline the process of decision-making. When this peculiar information and experience are used in a rational and professional field of sport management, the organizations could be more effective. In general, the majority of volunteer sport directors were athletes or referee in past. Nevertheless, these sport experience is important to be choose for an elected position in the sport organization.

The president's ability to anticipate a discussion was like a political statement, and

Anticipation in the debate thus entails a capacity of great importance. When the board's president expressed an opinion immediately after presenting the problem/issue, he would influence several interventions and consequently, the final decision.

The use of formal and regular authority by the president in the managing of the

Formal authority decision-making process. This authority is given by the statutes and rules of organizational structure in order to respect the board's mission and the values of organization. 
Meeting's observation memo: "The board's president had done his homework. He presents the issues, adds the key elements, shares the information and the performed tasks, and starts the discussion. Nevertheless, the solution has already been found. The board colleagues do not have the chance to suggest alternatives. In fact, they are not prepared and they trust the president. As the president works in full-time basis, he has much more time to contact, research, and analyze, etc. In this way, he ensures an apparent professional work".

The previous quote was confirmed during the interview, as it follows:

I think our experience has been different, since both of us are managers in a full-time basis - with a seconded situation. At this time it would be insufficient to conduct this association with only a few hours a day, or during the weekend and only with a meeting every two weeks. We've been trying to develop a professional management. Moreover, we have the advantage to be expertise in Sport and Physical Education. (...) All of this, associated to the fact that we are totally available, brings benefits to the association's management. (Ent. Table Tennis, UT 71)

Still in the control of information as source of power, the results revealed the major role of the president. Especially in what concerns the mastering of the information related to competition, arbitration and sports results of the sports association. Furthermore, the majority of the board's sports leaders are old practitioners of the sports discipline. In this context, they dominate with ease matters such as technical, competitive and arbitration ones; and thus they had more power and influence for the decision-making. In fact, knowledge and experience in sports activity represents a source of power in the decision-making. Thus, the sport management skills, when associated with strategic capability and entrepreneurship sport based, can be useful for the boards' role in the making-decision process. A sport marketing strategy is also crucial to create a sustainable program offered by the sport organizations (RATTEN, 2016).

Four out of six technical directors of sport had a major role in the decision-making concerning activities and competitions at the level of specific knowledge, regulation and pedagogy of each sports discipline and providing data from sports results, competitions and activities plan. The technical director of sport was a key actor supporting the president regarding all issues related to competition and organization of sports activities. This role was even more important in the organizations where the leader was a volunteer, and thus, with no time to monitor and implement all board decisions with efficacy. In this context the role of technical sport director or sport manager 
is crucial to stimulate the pro-activity and innovation in the making-decision process. In recent years, the emphasis on the external context of sports organizations has increased as consumers give more importance to sustainability programs and are more involved. For example, sports events and teams influence the development of a community by encouraging participation in sport and sportrelated activity such as sport competition or sport and tourism (RATTEN, 2011).

When the president reveals argumentative capacity throughout the discussion, he is objective and based everything on accurate data, often with measurable indicators allowing substantiating his position and thus something to consider in the decision-making. This internal determinant is potentially related to expertise. Indeed, the greater the control over the flow of knowledge and the access to the affairs, the greater the odds to argument, particularly when it comes to the president. In the same line, lack of knowledge and unreadiness in certain subjects by several board members, has turned the discussion easy and unresponsive. While this data reveals once again the importance of the president's role in the decision-making process, it also suggests a fragile interactive debate. This happens if the sports directors do not prepare themselves, with the instruments and significant information, in order to gain power of arguing and participating. This state of affair becomes even more worrying if the head of the board, or one of his closest collaborators (vice-president or technical director of sport), does not gather crucial information for the argumentation and decisionmaking.

\section{The alliance between two or more actors as a source of influence on decision-making}

The establishment of alliances or agreements between two leaders was fundamental among every association. These alliances represented a source of influence in the decision-making process. These data were sustained in several phases of the study, and helped to classify a model as a bilateral model of decision (13.45\%). It was also found that a significant percentage $(63.66 \%)$ of the consensual decisions were influenced by a joint position of the main actors (president and vice-president). The alliance between the president and the technical director of sport was noticeable, particularly when the associations were led by a volunteer. As full-time professionals, the technical directors of sport kept the matters with additional depth. They also had more power controlling the information related with physical and sports activities, as well as the issues related with the affiliated clubs. In accordance with the integrated analysis of the data gathered through the interviews, there are two factors that might easily explain the alliance between the board directors, or between any of them and the technical director, namely: better control of matters under appraisal, compared to other sports directors, a decisive role in the overall planning and implementation of the sports competition, and in the management of the interests and affairs regarding the clubs, coaches and stakeholders. The associations that presented internal alliances in a more overt way, between 
two or more leaders, had the president and the director or vice-president in charge of the financial part (associations of Athletics, Canoeing and Volleyball), except the Basketball Association. It is likely that the financial matters foster greater understanding and solidarity between these two actors - for its specific and enhanced responsibility. In line with the previous case, the leaders in charge of the financial resources seem to exhibit expertise and skills in the field of finance and accountancy.

It was possible to notice a 'struggle' movement between leaders of two regional associations (at national level) and affiliated clubs, in order to obtain support (number of votes and financial resources) and stronger alliances. This happened at the regional and national levels, which is in accordance with the literature that highlights the dimensions of the agency theory (dependence on financial resources) (BROWN, 2005) and the political and stakeholder theory (group interests) (CLARKE, 2004; YEH; TAYLOR, 2008). For instance, to be represented in the national sports federation assembly where sports competitions programs are, as well as criteria to support the affiliated and sport associations are decided. Within this 'power games', the sports association's direction involvement was obvious. The association's leaders studied and assessed the scope of alliances towards obtaining benefits and compensations, at the level of the federation intervention. Indeed, there was not only a negative assessment but also a dissatisfaction regarding the work and support provided by the national federation. In the political model of organizations, Mintzberg (1995) has pointed out that technical knowledge games (not allowed) and unit's alliance are used in order to form a base of power. Through the observation memos' analysis gathered during the meetings, the existence of alliances among the leaders in order to expand the base of influence is quite obvious:

Observation's memo of the Tennis Table association: "Once again, we observed and confirmed an almost perfect understanding between the president and the vice-president. It seemed that they had previously studied and discussed the issues advanced throughout the meeting. It is very likely that this was able to happen, since they are both working in full-time basis and with the same schedule, in the same room.

The results also highlight the importance of certain skills - e.g., communication, shared and democratic leadership - displayed by the board president in order to obtain a consensual decisionmaking. One of the reasons for the openness to dialogue, and good understanding among all the elements, might be the benevolent character of the leaders and the friendship between most of the governing bodies' members. It should also be stressed that the board depends on the leaders' choice, which is endorsed by the electoral process. The technical director of sport can participate or not in the meeting, depending on the president's decision. These are sports organizations headed by volunteers, where there is a lack of transparency on each role. Actually, some promiscuity is 
perceptible in their positions in order to keep the control of information and the influence to the decision-making. Other studies results confirm the absence of a clear relationship, roles' definition, and exemption for a good governance practice (AGUILERA; CUERVO, 2004; FERKINS; SHILBURY; MCDONALD, 2005). This would help to make the organization more efficient and utilize greater corporate social responsibility (FERKINS; SHILBURY, 2012). Thus, the decision as a dynamic group is relevant to increase the engagement of the sport directors or the sport management in the organizational practices and to improve the organizational performance (BROWN, 2005; QUINN; ROHRBAUGH, 1983).

\section{Director's experience and involvement in the sports discipline}

The results gathered from the observation and the interviews show that the background's sports leader (not only the president of a sports discipline) - as an athlete, referee or even as a sport leader - provides him a peculiar power and influence in the process of decision-making. In general, the majority of volunteer sport directors were athletes in the past and this sport experience is important to be choose for an elected position in the sport organization. In this way, there was a higher involvement of the president in the subjects and matters related to competitions, training and technical and sports domains. One of the professional sports leaders acknowledged the significance of the sport's path and expertise:

"It is not easy to properly perform the duties of a sport leader in this sport's discipline if the person does not have any experience. This is something very complex and specific. I've always been closely linked to this sport's discipline, and that is why I'm able to deal with the problems and issues that come up - that does not mean that I'm more capable. I understand that someone with a particular training, with good and clear ideas has the chance to be a good leader". (Observation's memo - clarification)

The results suggest that the roles' clarification between leaders - i.e., volunteers or professionals-, and the sports technicians or sports managers at the middle management level, promotes optimizing the decision-making. On one hand, sports managers and technical directors of sport control the day-by-day of an organization, however, the decision-making depends on the board's leaders. In fact, the roles' clarification between the board and the professional sports manager is one of the most evident conclusions that come out from the research regarding the volunteer sports organizations (AULD; 1994; HOYE; CUSKELLY; 2003; SHILBURY; FERKINS; 2011). The upward trend to professionalize the structures, as well as the processes within the volunteer sports 
organizations make them more rational, efficient and specialized (NAGEL et al.; 2015; CHALIP, 2006). Sport-based entrepreneurship is crucial for this sports associations in order to respond to an opportunity to create value (RATTEN, 2011). The role of sport manager is relevant to increase the pro-activity, the innovation and the risk for the board decision. In this study, a positive relationship was evident between the degree of board's professionalization and intermediate management (sports management or technical direction) and the strategic achievements. The associations headed by professional presidents and supported by the technical director of sport presented the following strategic achievements: greater ability to raise athletes and affiliated clubs, good sportive results at national competitions, higher rates of international athletes and with Olympic potentialities, greater ability to develop partnerships and their own revenues.

\section{The president's anticipation in the debate}

The president's ability to anticipate a discussion was like a political statement, and thus entails a capacity of great importance. From the data collection, it was possible to verify that the board president expressed his opinion immediately after presenting the problem and opening the debate. In this way, he would influence several interventions and thus, the final decision. The following memo illustrates it:

\section{Observation's memo: Following his explanation, the board's president thinks that: "what is intended is to recast the competition model, and change the technical and pedagogical regulation, if we think it should be changed". He also highlighted: "our goal is to give a new look, that is stop being only a party. I think the competitive dimension in this class should be valued; just like in the neighboring island's model".}

When the president of the board presents a problem during a meeting he controls the debate in order to offer a solution or an idea. Usually, this happens before he asks the board colleagues to participate. In an open and active process of participation, this would be different, since he would promote a debate, as well as asking for other's ideas. Nevertheless, what we have observed was an anticipated decision, which was showed and justified as the best solution. One can assume that this is an ability of the president to convince and persuade the sport directors of the board to join the leader's proposal.

This dimension might represent a greater power source, since the president holds the control of the flow of information and presents a higher level of preparation than his board colleagues. It should be stressed that this ability was more evident among the associations with professional leaders maybe because they had greater knowledge concerning the issues and problems. 


\section{The use of formal authority by the president}

Most of theoretical models that explain the organizations as a political organization, point out the authority of the president as one of the most explicit power sources in the hierarchical structure (MINTZBERG, 1995). However, no substantial result was found to say that the president used this power over the other board members, during the debate and the decision-making process. This only happened with the issues related to financial resources. In general, the prevalence was openness to dialogue, which was fed by a leadership style, with a consensual approach and respect to others' positions. Additionally, some data demonstrate the communication ability as a key factor that influences and impassions the colleagues for a consensual decision. The Table Tennis association illustrates above as stated below:

Meeting observation's memo: With openness to dialogue, the president called the attention for the nature of the debate and the importance to a consensual position among all members. Yet, as the president noted, whenever this understanding is not possible, there is the majority decision. In case of a tie vote (absence of a board member), the president had the casting vote.

It is likely that the board president's leadership style is a consequence of the circumstances. This is an organizational structure without a clear role's definition, which is based on consensus and alliances between the best-placed actors of the 'game'. In addition, an affinity between some board members was noticeable, which enhances mutual commitment relationship, not confrontation.

\section{Managing implications for sport directors}

Considering the patterns of the decision-making process and the president's role, this study concludes that the majority of the decisions have been taken through the consensus among the board leaders. The decision-making process, through the understanding of two or more elements, has also achieved a considerable percentage - $13.45 \%$-, particularly between the president and the vice-president. The alliance between these two leaders, in association with the control of the information flow, built a very relevant internal source of power, especially for financial matters. On the other hand, in Basketball Association - where the president was more 'absent' - the insufficiencies concerning the control of flow information, regarding the files by the board members (because they were volunteers), were overcome by the technical director of sport. His greater ability in management and implementation was very useful and has provided a complicity and alliance with the president in several strategic matters. This was evident during the organization of regulations and regional and national competitions. Furthermore, it is also concluded that the technical director of sport or sports manager is a key element in the strategic management's control. The technical 
director also plays a set of functions at the directorate level, i.e. human resource management, sports season planning, communication and relationships with the technical bodies of the sports clubs and coaches, and training guidance of the national team athletes. In the context of sport associations as nonprofit organizations that are depend on the sport stakeholders, it is crucial to develop a sport based entrepreneurship characteristics. Innovation and pro-activity are important for sport management, so it is possible to develop a strategic capability, create value, especially in an open marketing (RATTEN, 2011). The role of sport manager or technical sport director in a marketing analyses is crucial to support the board decision. The organization of sport competition tournaments or sport events are good opportunities to innovate and to create value. Indeed, these events can promote big and high qualitative sport competitions, which are attractive to the best players/teams. In order to make this possible is mandatory to involve sport partnerships and sponsorships, so one creates conditions to prepare the best players for national and international level of sport competitions.

According to the global and internal analysis of the board president's role, it cannot be concluded that he would use his formal authority - given by the internal rules - to set the direction of the decision-making process. There is also no evidence that the president has centered or abused his own authority to control the decision-making process. Therefore, it is concluded that the president adopts a model of democratic participation and encourages good social atmosphere and commitment among the volunteer leaders. However, it is necessary to take into account that the board members' activity was generally characterized by their poor preparation of the discussed issues - this is applied to volunteer members. That is why the board president's role and influence were relevant for the decision-making process. In this way, it is suggested that some specific skills of the president are fundamental to his strategic ability, as well as to control the making-decision process, a good control of the information and issues in question, which corresponded to a bigger influence on decision-making process. Likewise, the presidents in professional collaboration (seconded) displayed more influence in the decision-making process than the volunteer leaders. For instance, in Athletics Association, the combination of various sources of power used by the president gave him strength in the decision-making process. These are some of his power sources: expertise regarding the decision-making process; readiness to accompany the organization problems and activities, by the fact he was working in full-time basis; the experience accumulated as a sports discipline leader; and a technical and specific knowledge of the sports discipline issues. The implication for the sport associations that are leaded by volunteer sport directors suggest a professional role in sport management field. Sport management skills connected with strategic capability and entrepreneurship sport based can could be useful for the boards' role in the makingdecision process. In a recreational perspective and a sport competition for all, the sport associations 
could be develop a dynamic sport marketing strategy in order to increase the participation in sport activity. Sport's marketing promotes sport participation and increases the visibility of sport as a recreational activity, for the reason that shows people they on it in several and different ways (RATTEN, 2016).

Through these results, it can be stated that the president's anticipation - expressing his position before the debate - was more evident and frequent when he had greater control over the information from both associations headed by professionals and in Basketball Association. Besides, the strategic outcomes and management capacity of the associations directed by professional leaders were superior compared to their volunteer counterparts.

\section{Future research directions}

In this study, results validate the findings of other studies applied to voluntary sports organizations. Likewise, lack of clarity in the roles of the board leaders and professionals was observed in the intermediate management (technical director of sport and sports manager), as well as some conflicts of interest between affiliated clubs and coaches. Similarly, an accumulation of positions and roles among voluntary directors (members elected by the affiliated clubs) and sports direction is an admissible practice in sports associations. The findings deserve some thought and reflection in terms of regulating, formalization, differentiation, transparency, and accountability in order to give credibility to the position of sports directors and board. Qualitative studies are needed to understand the relationship between the board and sport manager. Thus, the sport associations need to adopt a code of ethics in order to increase their transparency and impartiality. In this sense it is necessary to develop studies about good governance and ethics, so we gather more data highlighting good practices and the use of sport as a social good.

This paper should have implication for the public policy planners who are interested in the evaluation of the role of stakeholder regional or local government. Indeed, sports associations are strongly dependent on public financial resources. Taking into account that the government's financial resources are diminishing and insufficient, sports associations must develop their own sports' marketing strategy.

Finally, in a stakeholder theory if we want to understand the role of different partnerships' role we should study the interests (power games) and goals of sport clubs, sport coaches and national sport federations. The regional or local sport associations do not have a completely autonomy and a full independence. Besides they are dependent on public financial resources, they are strongly connected with the group interests of sport clubs and sport coaches. This is a new and complex gap we must deep in. 
We also have to highlight the relevance of the sport management field and the sport manager role within the volunteer sport context, especially in sport associations led by volunteer sport directors.

\section{REFERENCES}

AGUILERA, R. V.; CUERVO CAZURRA, A. Codes of governance worldwide: what are the triggers? Organization Studies, v. 25 n. 3, 415-443, 2004.

AULD, C. Changes in Professional and Volunteer Administrator Relationships: implications for managers in the leisure industry. Australian Journal of Leisure \& Recreation, v. 4 n. 2, 14-22, 1994.

BLACK, B. S.; JANG, H.; KIM, W. Does corporate governance predict firms' market values? evidence from Korea. The Journal of Law, Economics, \& Organization, v. 22, n. 2, 363-413, 2006.

BROWN, W. Exploring the Association Between Board and Organizational Performance in Nonprofit Organizations. Nonprofit Management and Leadership, v.15, n. 3, 317-339, 2005.

CAIXE, D. F.; KRAUTER, E. The Relation between corporate governance and market value: mitigating endogeneity problems, Brazilian Business Review, v. 11, n. 1, 2014.

CARVER, J. Boards that make a difference a new design for leadership in non-profit and public organizations. San Francisco, Calif.: Jossey-Bass, 1997.

CHALIP, L. Toward a Distinctive Sport Management Discipline. Journal of Sport Management, v. 20, 1-21, 2006.

CLARKE, T. Introduction: Theories of Governance-Reconceptualizing Corporate Governance Theory After the Enron Experience. Em T. Clarke, Theories of corporate governance: the philosophical foundations of corporate governance (pp. 1-30). New York: Routledge, 2004.

FERKINS, L. S.; SHILBURY, D.; MCDONALD, G. The Role of the Board in Building Strategic Capability: Towards an Integrated Model of Sport Governance. Research Sport Management Review, v. 8, 195-225, 2005.

FERKINS, L.S. Developing board strategic capability in sport organisations: The national-regional governing relationship. Sport Management Review, v. 13, 235-254, 2010.

FERKINS, L. S. Board involvement in strategy: advancing the governance of sport organizations. Journal of Sport Management, 23, 245-277, 2009.

FERKINS, L. S.; SHILBURY, D. Good Boards Are Strategic: What Does That Mean for Sport Governance? Journal of Sport Management, v. 26, 67-80. 2012.

FERNANDES, F.; LUCAS, J. Autonomia Política e Desenvolvimento Desportivo - uma Experiência de Gestão Desportiva da RAM, Comunicação realizada na conferência de Gaia - Sistema Desportivo Português - que modelo?, Confederação do Desporto de Portugal, 2003.

HEALEY, D. Governance in Sport: Outside the Box? Economic and Labour Relations Review, v. 23, n. 3, 39-60, 2012.

HOYE, R. Commitment, involvement and performance of voluntary sport organisation board members. European Sport Management Quarterly, v. 7, n. 1, 109-121, 2007. 
HOYE, R.; CUSKELLY, G. Board - Executive Relationships within Voluntary Sport Organisations. Sport Management Review, v. 6, 53-74, 2003.

HOYE, R.; CUSKELLY, G. Sport Governance. Boston: Elsevier. Hums, 2007.

HUMS, M. A.; MACLEAN., J. C. Governance and Policy in Sport Organizations. Aston, PA: 3rd Edition, Holcomb Hathaway Publishers, 2013.

INGLIS, S. Roles of the Board in Amateur Sport Organizations. Journal of Sport Management, v. 11, n. 2, 160-176, 1997.

KIKULIS, L. M. Continuity and Change in Governance and Decision Making in National Sport Organisations: Institutional Explanations. Journal of Sport Management, v. 14, 293-320, 2000.

MADELLA, A.; BAYLE, E.; TOME, J. L. Performance measurement of sports national organisations in Europe: A comparative analysis between four national swimming federations. European Journal of Sport Science, v. 5, 207-220, 2005.

MAXWELL, J. A. Qualitative Research Design: An Interactive Approach. London: Third Edition, Sage, 2013.

MINTZBERG, H. Inside our strange world of organisations. New York: The Free Press, 1989.

MINTZBERG, H. Estrutura e dinâmica das organizações ( $1^{\mathrm{a}}$ ed.). Lisboa: Publicações Dom Quixote, (1995).

MINTZBERG, H.; QUINN, J. B.; GHOSHAL, J. The strategy process. London: Prentice Hal, 1995.

NAGEL, S.; SCHLESINGER, T.; BAYLE, E.; GIAUQUE, D. Professionalisation of sport federations - a multilevel framework for analysing forms, causes and consequence. European Sport Management Quarterly, v. 15, n. 4, 407-433, 2015.

PALMER, D. Governance of voluntary sport organizations. Em L. Robinson, \& D. Palmer, Managing voluntary sport organisations. (pp. 33-50). Oxford: Routledge, 2011.

QUINN, R. F.; ROHRBAUGH, J. A Spatial Model of Effectiveness Criteria: Towards a Competing Values Approach to Organizational Effectiveness. Management Science, v. 29, 363-377, 1983.

RATTEN, V. The dynamics of sport marketing. Marketing Intelligence \& Planning, v. 34, n. 2, 162-168, 2016.

RATTEN, V. Sport-based entrepreneurship: towards a new theory of entrepreneurship and sport management. Int Entrep Manag, v. 7, 57-69, 2011.

ROBINSON, L.; PALMER, D. Managing Voluntary Sport Organizations. London and New York: Routledge, Taylor \& Francis Group, 2011.

SCHULZ, J., AULD, C. Perceptions of Role Ambiguity by Chairpersons and Executive Directors in Queensland Sporting Organizations. Sport Management Review, v. 9, 183-201, 2006.

SHILBURY, D.; FERKINS, L. Professionalization, sport governance and strategic capability. Managing Leisure, v. 16, n.2, 108-127, 2011.

SHILBURY, D., FERKINS, L., \& SMYTHE, L. Sport governance encounters: Insights from lived experience. Sport Management Review, v. 16, n. 3, 349-363, 2013. 
SOARES, J. Conflicts of Interests or Complementarity between the Role of Volunteer Sport Director and Sport Manager in Sport Associations. XII Forum of European Network of Sport Science, Education and Employment, Groningen (pp. 10-11). Groningen Holland: Hanze University of Applied Sciences, School of Sport Studies, 2013.

SOARES, J.; CORREIA, A.; ROSADO, A. Political Factors in the Decision Making Process in the Voluntary Sports Associations. European Sport Management Quarterly, v. 10, n. 1, 5 - 29, 2010.

VROOM, V.; JAGO,A. The New Leadership: Managing Participation in Organizations. Englewood Cliffs, NJ: Prentice-Hall, 1988.

YEH, C. M.; TAYLOR, T. Issues of governance in sport organisations: a question of board size, structure and roles. World Leisure Journal, v. 50, n. 2, 33-45, 2008. 